Грицюк В. В. ${ }^{1}$;

Кульчицький О. С. ;

Зотова I. Г.,;

Гудим В. М. ${ }^{2}$

1 - Центр воєнно-стратегічних досліджень Національного університету оборони України імені Івана Черняховського, Київ;

2 - Інститут державного військового управління Національного університету оборони України імені Івана Черняховського, Київ

\title{
Аналіз сучасної нормативно-правової бази у сфері електронної ідентифікації та автентифікації користувачів існуючих та перспективних інформаційних систем
}

Резюме. У статті проведено аналіз нормативних актів, стандартів та процедур електронної ідентифікації та автентифікації користувачів існуючих та перспективних інформаційних систем.

Ключові слова: ідентифікація, автентифікація, нормативно-правова база, персональні дані, електронний цифровий підпис, електронний реєстр, ідентифікатори, ідентифікаційні дані.

Постановка проблеми. Розвиток систем та засобів ідентифікації та автентифікації користувачів існуючих та перспективних інформаційних систем в Україні 3 додержанням високого рівня гарантій електронної ідентифікації, надає широкі можливості взаємодіяти 3 надавачами сервісів та послуг на новому зручному та якісному рівні [0].

Наша держава обрала курс євроінтеграції, що вимагає приведення у відповідність вітчизняних нормативних актів, стандартів та процедур. Виникає потреба детального аналізу стану та трендів цієї сфери як в Україні, так і в країнах Європейського Союзу.

Проведений аналіз допоможе розв'язати задачу побудови нормативного та технічного підгрунтя у сфері електронної ідентифікації та автентифікації користувачів існуючих та перспективних інформаційних систем.

У цьому аспекті постануть завдання із забезпечення правового, організаційного, понятійного та технологічного взаємоузгодження (інтероперабельності) як на національному рівні, так і на міжнародному.

Окрім позитивних результатів у політичному, економічному, юридичному та науково-технічному контексті від впровадження сучасних засобів електронної ідентифікації та автентифікації в Україні, слід враховувати ментальне ставлення суспільства до такого впровадження - небажання утримувати додаткові засоби, що ідентифікують особу, втрачати час та матеріальні ресурси.
Аналіз останніх досліджень i публікацій. Дослідженню проблем ідентифікації та автентифікації інформаційних систем, оцінюванню надійності застосування алгоритмів і методів захисту інформації значну увагу приділяли провідні вітчизняні та зарубіжні науковці, зокрема Л. Адлеман [0], А. І. Березовський [0], Л. Ю. Боков [0], А. М. Боровиков [0], Л. А. Завадська [0], В. К. Задирака $[0,0]$, Р. Є. Сміт [0], А. М. Фаль [0], Л. Б. Шевчук [0, 0], О. К. Юдін [0].

Метою статті $€$ аналіз сучасної нормативно-правової бази у сфері електронної ідентифікації та автентифікації користувачів існуючих та перспективних інформаційних систем.

Виклад основного матеріалу. Основоположними нормативно-правовими актами, якими регламентуються засади розвитку схем та механізмів електронної ідентифікації та автентифікації в Україні є: Цивільний кодекс України; Податковий кодекс України; Закон України "Про інформацію"; Закон України "Про державну реєстрацію актів цивільного стану"; Закон України "Про захист персональних даних"; Закон України "Про доступ до публічної інформації; Закон України “Про електронний цифровий підпис"; Закон України "Про захист інформації в інформаційно-телекомунікаційних системах"; Закон України "Про Єдиний державний демографічний реєстр"; Закон України "Про державну реєстрацію юридичних осіб та фізичних осіб - підприємців"; Правила забезпечення захисту інформації в інформаційних, телекомунікаційних та 
інформаційно-телекомунікаційних системах, затверджені постановою Кабінету Міністрів України від 29.03.2006 № 373;

Важливою проблемою, яка постає перед розробниками схем електронної ідентифікації та автентифікації інформаційних систем, є неузгодженість нормативних визначень, а також підходів до обрання та додержання відповідного рівня гарантій автентифікації користувачів інформаційних систем.

Для прикладу слід відзначити достатньо різні визначення терміну “ідентифікація" у різних нормативних актах. Слід зазначити, що нормативними документами лише частково розмежовано терміни та відповідні процедури, що відносяться до ідентифікації особи за участю сторонніх осіб або із застосуванням інформаційних систем, тобто автоматизованим способом.

Визначення "особа" взагалі, відповідно до нормативно-правових актів України, стосується як фізичних так і юридичних осіб. Відповідно до Цивільного кодексу України, фізична особа - це людина, що є учасником цивільних відносин, натомість юридична особа - це організація, утворена i зареєстрована у встановленому законом порядку.

Для ідентифікації особи за безпосередньої участі інших осіб (здебільшого, фізичних осіб, які є посадовими особами) у вітчизняних нормативно-правових документах передбачається ототожнення фізичних або юридичних осіб за сукупністю даних, які відповідно до документів, виданих уповноваженими органами, що унеможливлює появу сумніву щодо особи, що звернулася для вчинення певних юридичних дій.

Законом України "Про нотаріат" передбачається, що "встановлення особи здійснюється за паспортом громадянина України або за іншими документами, які унеможливлюють виникнення будь-яких сумнівів щодо особи громадянина, який звернувся за вчиненням нотаріальної дії”. Водночас перелічені документи, відповідно до яких можлива чи не можлива ідентифікація особи.

у різних законах визначення “ідентифікація особи” подається 3 двояким тлумаченням, наприклад, Закон України "Про банки і банківську діяльність” роз'яснює цей процес як встановлення власника на підставі документа, а в Законі України "Про Єдиний державний демографічний реєстр" визначається, що цей процес являє собою перевірку наданих даних у картотеках, базах даних, реєстрах [0].

Окремо необхідно звернути увагу на термін “персональні дані", який наведено у Законі України "Про захист персональних даних", за яким визначено, що це сукупність відомостей про фізичну особу, яка ідентифікована або може бути ідентифікована. У цьому понятті тлумачиться визначення “ідентифікація особи”. Це поняття та його зміст $\epsilon$ ключовим при розгляді питань електронної ідентифікації та автентифікації в інформаційних системах.

Ще заплутанішою $є$ ситуація 3 описом процесу ідентифікації та автентифікації осіб як користувачів інформаційних систем, у тих випадках, коли дія відбувається в автоматичному режимі.

Відмінними від термінів "фізична особа" та “юридична особа", що застосовуються у “нецифровому полі", є визначення "користувача інформації в системі”. Згідно Закону України "Про захист інформації в інформаційно-телекомунікаційних системах" це фізична або юридична особа, яка в установленому законодавством порядку отримала право доступу до інформації в системі. Закон України "Про електронний цифровий підпис" визначає термін "підписувач" як особу, яка на законних підставах володіє особистим ключем та від свого імені або за дорученням особи, яку вона представляє, накладає електронний цифровий підпис під час створення електронного документа.

Крім того у Законі України "Про електронний цифровий підпис" визначено: “електронний цифровий підпис - вид електронного підпису, отриманого за результатом криптографічного перетворення набору електронних даних, який додається до цього набору або логічно з ним поєднується і дає змогу підтвердити його цілісність та ідентифікувати підписувача".

Таким чином, зазначеним документом описаний механізм ідентифікації окремої категорії осіб - користувачів автоматизованих (інформаційних) систем (підписувачів). Однак це відноситься лише до ситуації, коли ЕЦП (електронний цифровий підпис) використовується для підтвердження цілісності електронних документів.

В інших підзаконних актах визначення терміну “ідентифікація” в рамках “цифрового" поля різниться.

Правила забезпечення захисту інформації в інформаційних, телекомунікаційних та 
інформаційно-телекомунікаційних системах. Затверджено постановою Кабінету Міністрів України від 29.03.2006 № 373 представляють термін “ідентифікація" як “процедуру розпізнавання користувача в системі, як правило, за допомогою наперед визначеного імені (ідентифікатора) або іншої апріорної інформації про нього, яка сприймається системою".

Наказ Міністерства економіки України "Про затвердження Порядку планування, формування, створення, функціонування, супроводження, систематизації електронних інформаційних ресурсів Міністерства економіки України та доступу до них" від 16.07.2010 № 854 визначає “ідентифікацію користувача" як “процедуру присвоєння користувачеві набору персональних електронних реквізитів (звичайно використовується пара логін-пароль) або надання йому спеціального електронного ключа, що перебуває в його ексклюзивному користуванні.

Згідно Наказу Державного комітету ядерного регулювання "Про затвердження Правил фізичного захисту ядерних установок та ядерних матеріалів” від 04.08.2006 № 116 "Ідентифікація особи" - це встановлення відповідності ідентифікаційних ознак людини, занесених у документи або базу даних, фактичним ознакам самої людини.

Таким чином, необхідно на нормативному рівні упорядкувати понятійну базу 3 питань електронної ідентифікації та автентифікації. Це $\epsilon$ умовою для побудови інфраструктури електронної ідентифікації та автентифікації користувачів існуючих та перспективних інформаційних систем із забезпеченням iї взаємосумісності як на технічному, так і на семантичному рівні та рівні політик.

Окремою проблематикою є унікальність ідентифікаційних даних (ідентифікаторів), які надають можливість ідентифікувати (визначити) об'єкт (фізичну чи юридичну особу, інформаційну систему) поміж представленої множини об' єктів.

У нормативно-правовому полі України представлений широкий набір ідентифікаційних даних, які застосовуються під час інформаційного обміну в інформаційних системах.

Основними, найбільш впливовими у громадян України, законодавчими актами є: Цивільний кодекс України; Податковий кодекс України; Закон України “Про Єдиний державний демографічний реєстр та документи, що підтверджують громадянство України, посвідчують особу чи ії спеціальний статус"; Закон України "Про державну реєстрацію юридичних осіб та фізичних осіб підприємців"; Закон України "Про державну реєстрацію актів цивільного стану"; Закон України “Про загальнообов'язкове державне пенсійне страхування"; Закон України "Про державний реєстр виборців".

Ці нормативно-правові акти визначають перелік даних, що надають можливість виокремити фізичну чи юридичну особу поміж інших суб'єктів для здійснення ділової, правової та соціальній взаємодії, укладання різнорідних цивільних актів та, зокрема, здійснення цієї або іншої діяльності під час інформаційної взаємодії.

Наразі законодавчими актами України визначено наступний перелік основних ідентифікаційних даних фізичних осіб: прізвище; ім'я; по-батькові; громадянство; дата i місце народження; дата смерті; стать; місце проживання; електронний (відцифрований) зразок підпису особи; електронний (відцифрований) образ обличчя особи; електронні (відцифровані) відбитки пальців рук; серія та номер паспорта (документа, що посвідчує особу); унікальний номер запису в Єдиному державному демографічному реєстрі; реєстраційний номер облікової картки платника податків - фізичної особи; цивільний стан або соціальний статус.

Проте існує практика, за якою громадяни України можуть змінювати основні ідентифікаційні данні (наприклад: прізвище (укладання шлюбу), ім'я, по-батькові (усиновлення), дату та місце народження), укладаючи акти цивільного стану.

Також людина може змінювати місце проживання, а інколи громадянство та стать.

3 плином часу у кожної особи змінюється образ обличчя та власноручний підпис.

Дані, що вказані в акті про смерть фізичної особи, повинні бути скасовані у випадку появи особи.

У законодавстві визначено, що електронні (відцифровані) відбитки пальців надаються лише за згодою особи.

Слід зауважити, що серії та номери документів, які посвідчують особу, а також щодо іiі цивільного стану чи соціального статусу, $є$ лише обліковими даними цих документів, і протягом життя особи не $\epsilon$ постійними та можуть бути змінені згідно процедури видачі дубліката або повної заміни у випадку втрати. 
Перелічені ідентифікаційні дані $\epsilon$ придатними для достовірної ідентифікації лише у певний момент часу. $\mathrm{Y}$ сфері електронної ідентифікації та автентифікації деякі ідентифікатори (ідентифікаційні дані) на будь-яких етапах обробки, наприклад, під час реєстрації користувача в інформаційній системі, можуть бути помилково введені. Це ускладнює процедуру перевірки (верифікації).

Таким чином, ідентифікаційні дані фізичних осіб повинні мати незмінний характер, використовувати формат, оптимальний для автоматичної обробки, 3 урахуванням розрахунку контрольної суми. Це дасть можливість запобігти помилковому введенню, а також забезпечить їх автоматичне формування. Такими ідентифікаторами, що відповідають зазначеним вимогам, слід визнати реєстраційний номер облікової картки платника податків - фізичної особи та унікальний номер запису в Єдиному державному демографічному реєстрі.

На сьогодні у нормативно-правовому полі України існує можливість відмови фізичної особи від отримання реєстраційного номера облікової картки платника у зв'язку зі своїми релігійними переконаннями. Згідно даних Державної фіскальної служби України близько 200 тисяч осіб відмовились від отримання "ідентифікаційного номера". У такому разі ідентифікація здійснюється за серією та номером паспорта громадянина України. Проблемою постає непостійність цих даних, про що було вказано вище. Також істотним $\epsilon$ те, що у країні відсутня система збору та обробки даних про діючі, загублені або визнані недійсними паспорти.

Як результат, застосування унікального номера Єдиного державного демографічного реєстру відповідно до Закону України "Про Єдиний державний демографічний реєстр" [0], що на практиці вже втілено під час видачі “біометричних" паспортів, передбачається перспективним, слугуватиме основою розбудови інфраструктури електронної ідентифікації та автентифікації.

Отже, слід відзначити необхідність внесення змін до нормативного-правового поля України для унормування використання унікального номера запису Єдиного державного демографічного реєстру, у якості єдиного ідентифікатора особи в будь-якій інформаційній системі. Це, в свою чергу, передбачає обмін ідентифікаційними даними між Єдиним державним демографічним реєстром та іншими реєстрами, наприклад: Державним реєстром актів цивільного стану,
Державним реєстром виборців, Державним реєстром фізичних осіб - платників податків, Державним реєстром застрахованих осіб, реєстрами майнових прав, базами даних судочинної системи тощо.

Висновки. У чинному законодавстві Україні сфера електронної ідентифікації та автентифікації не є системно урегульованою. Наразі ведеться робота 3 реформування законодавства, зокрема, до Верховної Ради подано до повторного розгляду у другому читанні Проект Закону "Про електронні довірчі послуги", який покликаний внести зміни у сфері використання інфраструктури відкритих ключів та надання електронних довірчих послуг з урахуванням досвіду Європейського Союзу, розбудови єдиного простору довіри на основі системи електронних довірчих послуг, визнання в Україні електронних довірчих послуг, які надаються іноземними постачальниками електронних довірчих послуг, що забезпечить активний розвиток транскордонного співробітництва та інтеграцію України у світовий електронний інформаційний простір.

\section{СПИСОК ВИКОРИСТАНОЇ ЛІТЕРАТУРИ}

1. Постанова Верховної Ради України "Про Програму діяльності Кабінету Міністрів України”, К., -11 грудня 2014 року - № 26-VIII.

2. [Електронний ресурс]. - Режим доступу : http://w1.c1.rada.gov.ua/pls/zweb2/

webproc4_1?pf3511=59139.

3. Закон України "Про Єдиний державний демографічний реєстр " [Електронний ресурс]. Режим доступу

http://zakon3.rada.gov.ua/laws/show/5492-17.

4. Adelman L.M., Huang M. A. Primality testing and Abelian varieties over finite fields.Lecture Notes in Mathematics, 1512: 142.

5. Березовский А. И., Задирака В. К., Шевчук Л. Б. О тестировании быстродействия алгоритмов и программ выполнения основных операций для ассиметричной криптографии // Кибернетика и системный анализ.- 1999.- № 5. - С. 56-66.

6. Березовський А. І., Задірака В. К., Мельникова С. С., Шевчук Л. Б. Деякі резерви оптимізації обчислень для множення багаторозрядних чисел // Теорія обчислень: Збірник. - К., 1999. - С. 325-329.

7. Боков А. Ю., Рахманов О. В. Обзор технологии пластиковых карт // Безопасность информационных технологий.- 1999.- № 2. - С. 47-53.

8. Юдін О. К. Захист інформації в мережах передачі даних / Юдін О. К., Корченко О. Г., Конахович Г. Ф. - К.: Вид-во ТОВ "НВП "IHTЕРСЕРВIC", 2009. - 716 с.

9. Боровиков А. М., Тимошенко А. А. Системы защиты информационного обмена "Клиент-Банк" // Безопасность информации.- 1995.- № 1. - С. 53-60. 
10. Завадская Л. А., Криптографически псевдослучайных Безопасность информс
Фаль А. М. сильные генераторы последовательностей //
11. Смит Р. Э. Аутентификация: от паролей до открытых ключей / Пер. с англ. - М. Виьямс, 2002. $432 \mathrm{c}$.

Стаття надійшла до редакції 08.11.2017

Грицюк В. В. ${ }^{\text {; }}$

Кульчицкий А. С. ${ }^{1}$;

Зотова И. Г. ${ }^{1}$;

Гудым В. Н. ${ }^{2}$

1 - Центр военно-стратегических исследований Национального университета обороны Украины имени Ивана Черняховского, Киев;

2 - Институт государственного военного управления Национального университета обороны Украины имени Ивана Черняховского, Киев

Анализ современной нормативно-правовой базы в сфере электронной идентификации и аутентификации пользователей существующих и перспективных информационных систем

Резюме. В статье проведен анализ нормативных актов, стандартов и процедур электронной идентификации и аутентификации пользователей существующих и перспективных информационных систем.

Ключевые слова: идентификация, аутентификация, нормативно-правовая база, персональные данные, электронная цифровая подпись, электронный реестр, идентификаторы, идентификационные данные.

\section{Hrytsiuk ${ }^{1}$;}

A. Kulchitsky ${ }^{1}$;

I. Zotova ${ }^{1}$;

V. Goodym ${ }^{2}$

${ }^{1}$ - Center for Military and Strategic Studies of the National Defence University of Ukraine named after Ivan Cherniakhovsky, Kyiv;

2 - Institute of State Military Management of the National Defence University of Ukraine named after Ivan Cherniakhovsky, Kyiv

Analysis of the current regulatory framework in the field of electronic identification and authentication of users of existing and prospective information systems

Resume. The article analyzes the normative acts, standards and procedures for electronic identification and authentication of users of existing and prospective information systems.

Keywords: identification, authentication, regulatory framework, personal data, electronic digital signature, electronic register, identifiers, identification data. 